\section{OCEAN GENERAL CIRCULATION MODEL SENSITIVITY EXPERIMENT WITH AN OPEN CENTRAL AMERICAN ISTHMUS}

\section{Ernst Maier-Reimer and Uwe Mikolajewicz}

Max-Planck-Institut für Meteorologie

Hamburg, Federal Republic of Germany

\section{Thomas Crowley}

Applied Research Corporation College Station, Texas

\begin{abstract}
We have tested the sensitivity of an ocean general circulation model to changes in solid boundary conditions by opening the central American isthmus in order to simulate possible circulation patterns existing prior to about 3.0-4.0 Ma. The model was driven by present winds, atmospheric temperatures, and moisture fluxes, with the only difference between control and perturbed runs being the open isthmus. Significant changes result for the perturbed case, almost all of which can be traced to changes in surface salinity distribution. With an open isthmus, lower-salinity waters from the Pacific dilute North Atlantic surface waters by $>1.0 \%$. The lower surface salinities cause the thermohaline cell in the North Atlantic to collapse, with North Atiantic Deep Water (NADW) production reduced to near zero. This response greatly weakens poleward ocean heat transport in the North Atlantic. The "noNADW" result appears to be insensitive to initial conditions and represents a circulation mode different than a "low-NADW" mode found in the same ocean model using present geographic forcing. There is some agreement between model predictions and geologic data, which indicate a significantly different deep-water circulation pattern prior to $\sim 2.4 \mathrm{Ma}$. However, observations suggests that the time of major transition in circulation regimes occurs earlier than the final closure of the isthmus. This discrepancy may reflect the fact that near-closure of
\end{abstract}

\section{Copyright 1990}

by the American Geophysical Union.

Paper number 90PA00577. 0883-8305/90/90PA-00577\$10.00 the isthmus by 7-10 Ma could have been sufficient to alter the circulation. As ocean heat transport is a key source of warmth to the high latitudes of the North Atlantic, some compensating factor $\left(\mathrm{CO}_{2}\right.$ ?) may have been required to restore warmth to that region prior to $\sim 3.0-4.0 \mathrm{Ma}$.

\section{INTRODUCTION}

Marine geologists have long been interested in the effect of "oceanic gateways" on the ocean circulation [e.g., Berggren and Hollister, 1974; Haq, 1981; Kennett et al., 1985]. Until recently we have only been able to make qualitative conjectures as to their effects. With the advent of large-scale ocean models and supercomputers we are now able to test these proposed scenarios. Geologic data can also provide a test for ocean models, for the conditions are realistic but sometimes radically different from the present. A large amount of marine geologic data can be used to validate such simulations.

One of the most well-known oceanic gateways involves the central American isthmus. This region was open for most of the Cenozoic, with closure finally resulting from eastward movement of central America as part of the trailing edge of the Caribbean plate (Figure 1). Biogeographic data can be used to more accurately date final closure (3.0-4.0 Ma), as the latter eliminated exchange of marine organisms and promoted the exchange of terrestrial biota [e.g., Keigwin, 1982b; Marshall et al., 1982]. However, both paleontologic and plate tectonic data (Figure 1) indicate that considerable constriction had occurred several million years earlier.

In this paper we will discuss results of an ocean general circulation model (GCM) experiment with an 

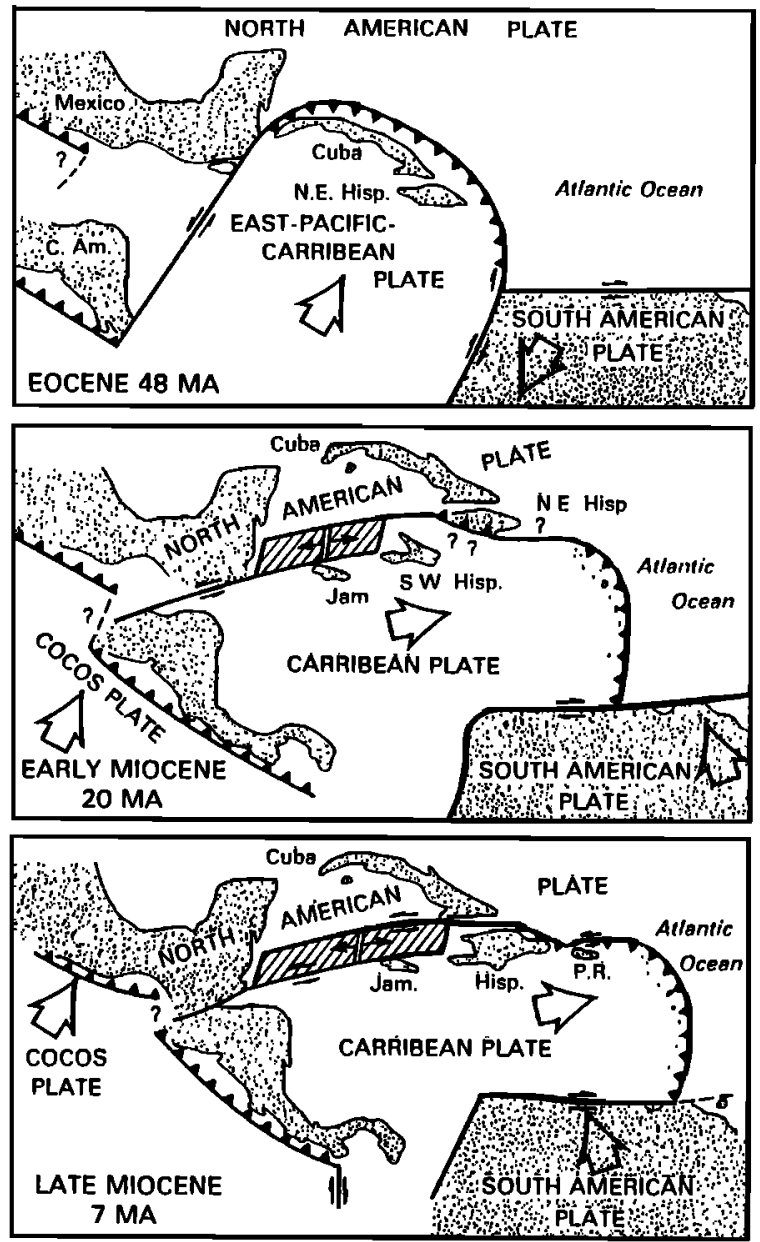

Fig. 1. Central American paleogeography before the closure of the isthmus, illustrating that the connection between the Atlantic and Pacific was closed off when the central American landmass, as part of the trailing edge of the Caribbean plate, was wedged between the Yucatan Peninsula and South America (modified from Sykes et al. [1982]).

open central American isthmus. We will demonstrate that the effects of an open isthmus are considerably greater than has heretofore been conjectured, for it affects both surface and subsurface flow. Model results have been validated to some degree with geologic data and have implications for hypotheses about the changing role of oceanic heat transport in the past.

\section{MODEL}

The model, hereafter referred to as the Hamburg model, is based on the standard set of equations used in numerical models. These are the conservation laws for salt, heat, and momentum, the latter in a linearized form. The equation for the vertical com- ponent of momentum is replaced by the hydrostatic approximation. The model was conceptually proposed by Hasselmann [1982]; details are discussed elsewhere [Maier-Reimer and Hasselmann, 1987; E. Maier-Reimer et al., manuscript in preparation, 1990]. Briefly, the circulation is divided into a barotropic component, consisting of the vertically averaged current and surface displacement fields, and a baroclinic component, consisting of the residual current after subtraction of the barotropic contribution. The formulation of the model is fully implicit, thus allowing a time step of one month. Equatorial Kelvin waves are formally included, but because of the coarse grid and the relatively long time step in integration, they are strongly damped. Outside the equatorial regions, the motion is essentially geostrophic, with frictional effects near the boundaries. Here the adjustment of the density field to the forcing is provided almost entirely by Rossby waves, as proposed by Hasselmann [1982]. On the time scales of interest sea ice and the salinity and temperature fields are prognostic variables, to which the velocities and the surface elevation equilibrate almost immediately.

For the present application the model was run on a $3.5^{\circ} \times 3.5^{\circ}$ grid, with 11 vertical levels, realistic bottom topography, and a full seasonal cycle. The circulation was driven by the observed wind stress field [Hellermann and Rosenstein, 1983] and air temperatures from the Comprehensive Ocean-Atmosphere Data Set (COADS [cf. Slutz et al., 1985; Woodruff et al., 1987]). When the model is run with observed forcing it is necessary to "taper" the model response to the climatologic boundary conditions to ensure smooth adaptation to observations. These "adaptation constants" are $1.5 \times 10^{-5} \mathrm{~m} / \mathrm{s}$ and $40 \mathrm{~W} / \mathrm{m}^{2}{ }^{\circ} \mathrm{K}$ for salinity and temperature, respectively. Given a mixed layer of $50 \mathrm{~m}$, this yields time constants for the mixed layer response to salinity and temperature changes of 40 and 60 days, respectively.

Surface freshwater fluxes for our baseline (stationary) experiment were determined by constraining the surface salinity to agree with the observed salinity field of Levitus [1982]. This was accomplished by imposing local changes of the water level in order to match the observed salinity with the actual salt inventory. These freshwater fluxes then modify any changes in surface salinity in other experiments due to altered boundary conditions (e.g., open isthmus).

The model does a reasonably good job of simulating the present surface and deep circulation in the ocean (e.g., Plate 1a and Figure 2). In the Atlantic cross-equatorial transport of North Atlantic Deep Water (NADW) is 17 sverdrups $\left(1 \mathrm{~Sv}=1 \times 10^{6}\right.$ $\mathrm{m}^{3} / \mathrm{s}$ ), a result approximately in agreement with observations [e.g., Gordon, 1986]. The large overturning yields a substantial heat transport across the equator from the South Atlantic to the North Atlantic, a result also in agreement with observations 

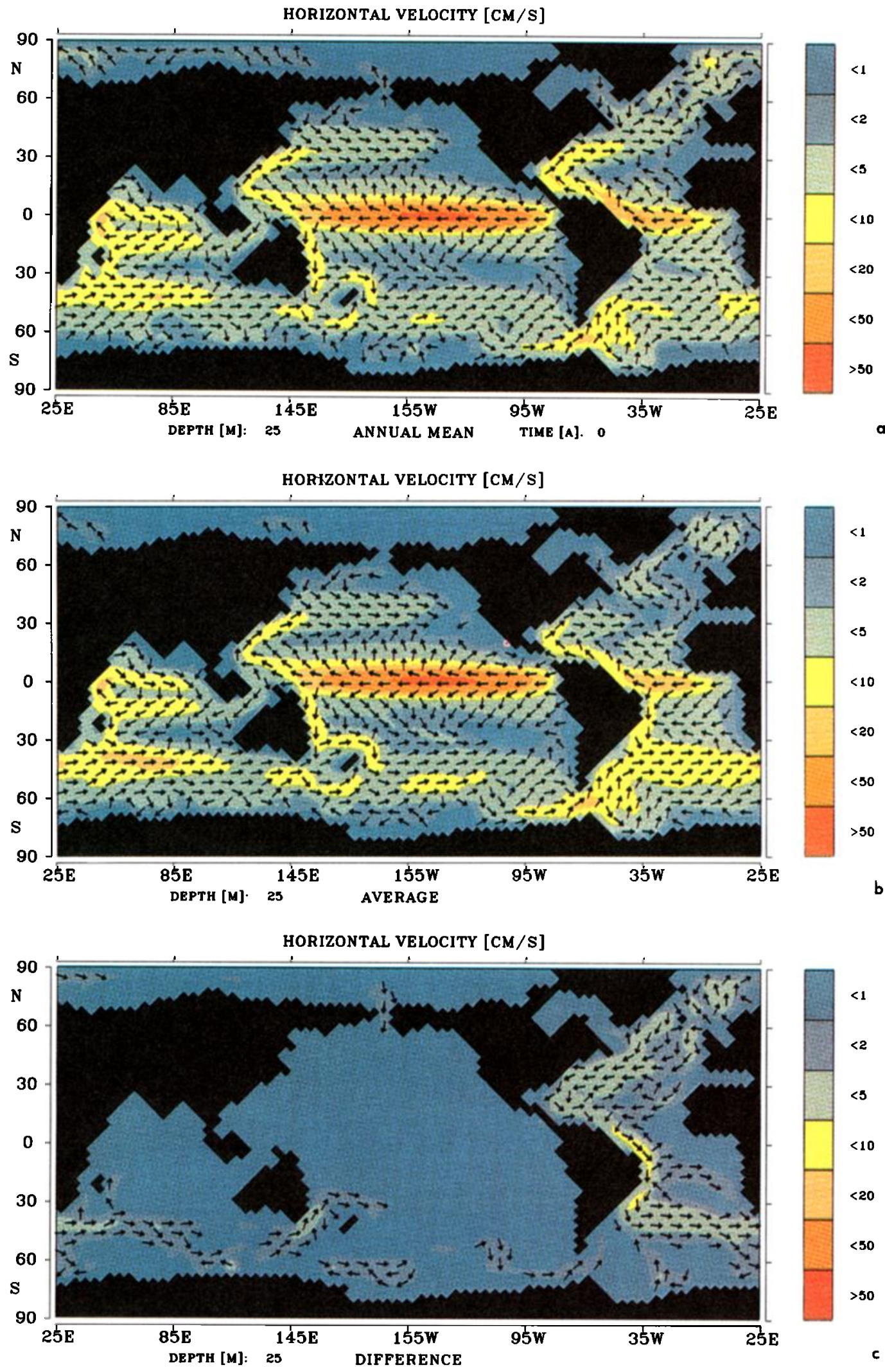

Plate 1. Surface circulation (25 m) for (a) control run; (b) Panama run; and (c) Panama-minuscontrol. 


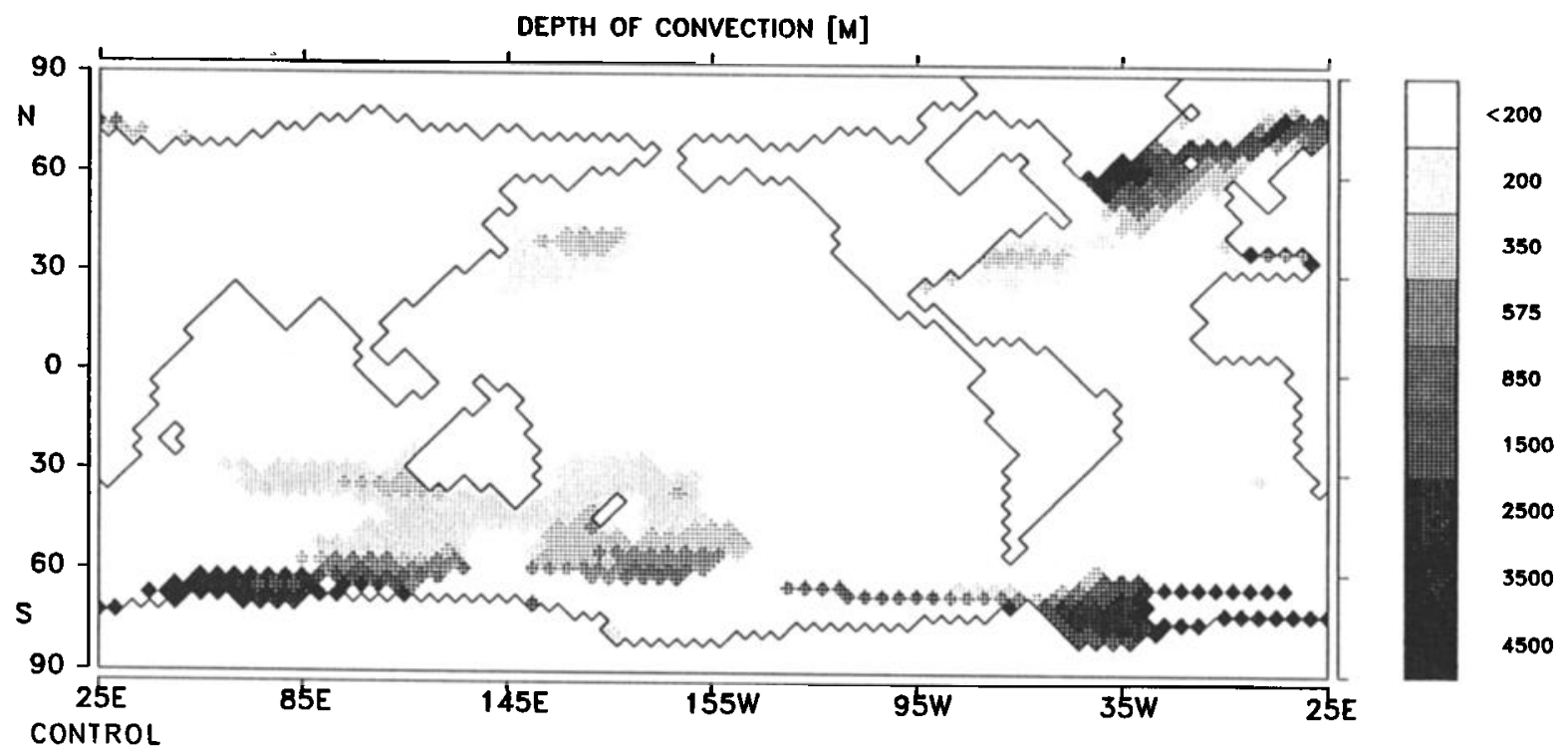

Fig. 2. Depth of convection (meters) in the control run. Note the general agreement between regions of deep convection and known regions of bottom water formation.

[Hastenrath, 1980]. In the Pacific the meridional circulation is dominated by the equatorial Ekman cell and a slow deep ventilation from the Antarctic.

Two main experiments were run: a control run for the present ocean and a perturbed run with an open central American isthmus. For the perturbed run we left open the region between the Yucatan Peninsula and the South American coast, with sill depth between them at $2711 \mathrm{~m}$ (we will attempt to evaluate the sensitivity of our results to the size of this opening in the discussion section).

The model was first spun up from a homogeneous ocean of $2.5^{\circ} \mathrm{C}$ and $34.5 \%$, with the described constraint on observed salinity. This experiment, termed the stationary experiment, was run for 10,000 years with a full seasonal cycle (30-day time steps). Including the seasonal cycle is important because it strongly influences the regions and frequency of overturning in high latitudes. The freshwater fluxes from the stationary experiment were then used in a control run by continuing the integration for another 4000 years. The obtained circulation field showed only slight differences to the spin-up; the circulation field for the last 500 years is defined as the control run.

For the perturbed run (termed "Panama," as in Panama Canal), we started with the steady state results of the control run and then removed the isthmus. This resulted in large oscillations during the first 1000 years, after which the model settled into its final pattern. Total length of the perturbed run was 8500 years, with the average of the last 500 years being used in the illustrations. As this simulation produced a deep-water pattern significantly different from the present, we ran two additional experiments to test the sensitivity of results to initial boundary conditions. We will describe these latter two experiments in the section where we evaluate the uniqueness of results.

\section{RESULTS}

The open central American isthmus had a profound effect on the three-dimensional circulation of the model ocean. Plate 1 illustrates the circulation for the control, perturbed, and difference fields $(25 \mathrm{~m})$. For the perturbed run, the western boundary current is weakened in the North Atlantic and substantially strengthened in the South Atlantic. The Antarctic circumpolar current is also generally stronger. One region that did not change much was the upwelling zone of the eastern equatorial Pacific. For example, Figures $3 \mathrm{a}$ and $3 \mathrm{~b}$ compare upwelling as estimated from the vertical velocity fields. Note that changes in upwelling are very small in the eastern equatorial Pacific. This result should be treated with some caution, as it is known that upwelling in this region is due to coupled ocean-atmosphere interactions. By fixing atmospheric forcing we may be artificially constraining this response.

Many of the above changes in the large-scale circulation can be understood by examining the fields of sea surface topography, surface salinity, and Atlantic meridional overturn (Figures 4-6). At present (Figure 4a) the long fetch in the zone of prevailing trade winds, coupled with the lower salinity in the Pacific, results in a higher surface topography in this basin (maximum of $80 \mathrm{~cm}$ ) than in the western 

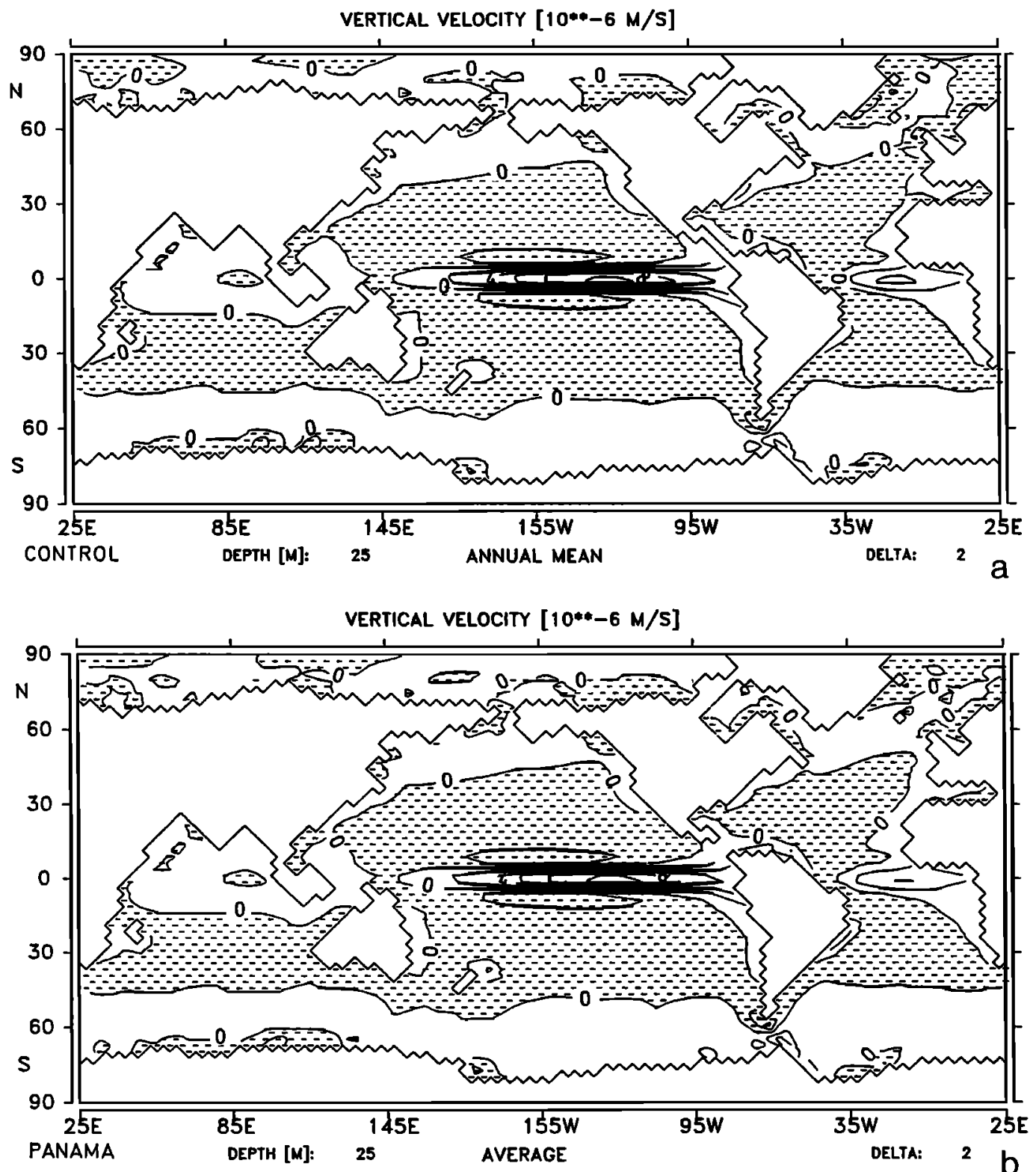

Fig. 3. Vertical velocity at $25 \mathrm{~m}$ (a measure of upwelling) for (a) control and (b) perturbed runs.

equatorial Atlantic $(0 \mathrm{~cm})$ or Norwegian Sea $(-80$ $\mathrm{cm}$ ). For the perturbed run (Figure 4b), the western Pacific "rise" is lowered to $60 \mathrm{~cm}$. There is a corresponding topographic rise in the equatorial Atlantic and a very large rise in the Norwegian Sea $(80 \mathrm{~cm})$. The changes result from the adjustment of the hydrostatic head between the two basins. With the open isthmus, this hydrostatic head causes a westeast downgradient flow of about $10 \mathrm{~Sv}$ from the western equatorial Pacific to the western equatorial Atlantic (there is still a 1-Sv east-west flow in the wind-driven surface layer, but the primary flow is from west-to-east).

The open isthmus allows low-salinity Pacific water to flow into the North Atlantic, diluting by $>1.0 \%$ 。 (Figure 5) the high-salinity waters in this ocean (at present the surface salinity of the North Atlantic is about $1.5 \%$ greater than the North Pacific; cf. Broecker, 1989). Surface salinity changes are larger in the subpolar North Atlantic (2.0-3.0\%o) because the initial perturbation alters the circulation, resulting in a change from northeasterly flow of high-salinity 

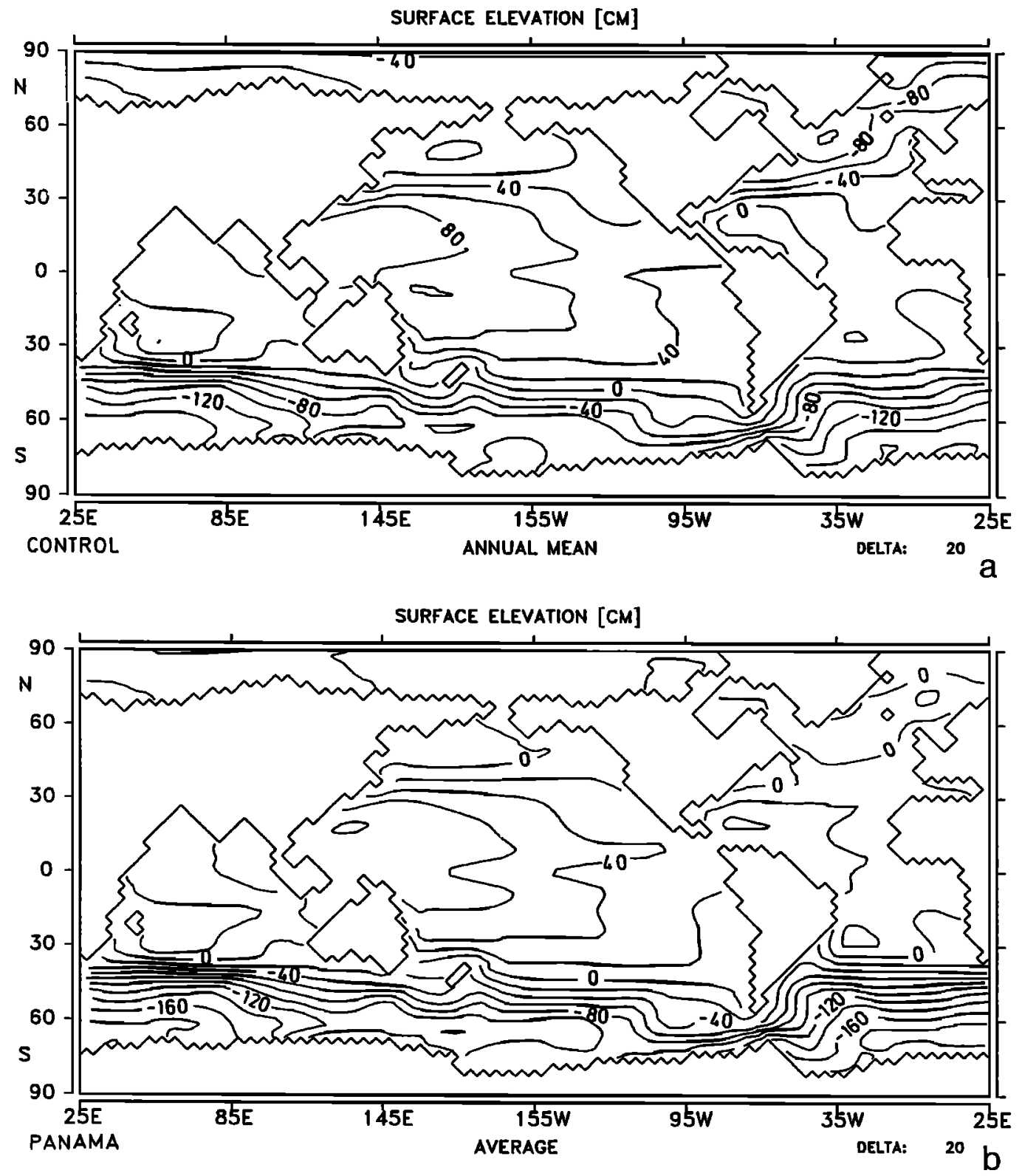

Fig. 4. Sea level topography (cm) for (a) control and (b) Panama runs.

water to southeasterly flow of low-salinity water. Low-surface salinities in the Norwegian Sea also eliminate the gradient in sea surface topography between the Norwegian Sea, the Arctic Ocean, and the subpolar North Pacific. In the perturbed run, flow between the Pacific and Arctic is reversed from the present pattern. Thus, although surface salinity increases in most areas of the Pacific, the low-salinity flow from the Arctic to the North Pacific decreases surface salinity in the subpolar North Pacific.

The low-surface salinities in the North Atlantic cause a chain reaction, for it prevents formation of
NADW (cf. Figure 6). Decreased NADW production decreases poleward ocean heat transport in the North Atlantic. Lower surface salinities in the subpolar North Atlantic also favor sea ice formation (Figure 7a; however, fixed air temperatures in the model may affect actual area of altered sea ice in the model). An increase in sea ice is consistent with decreased heat flux from the ocean to the atmosphere in this region (Figure $7 \mathrm{~b}$ ).

The collapse of the North Atlantic thermohaline circulation has a corresponding feedback on the South Atlantic circulation. At present, the North 

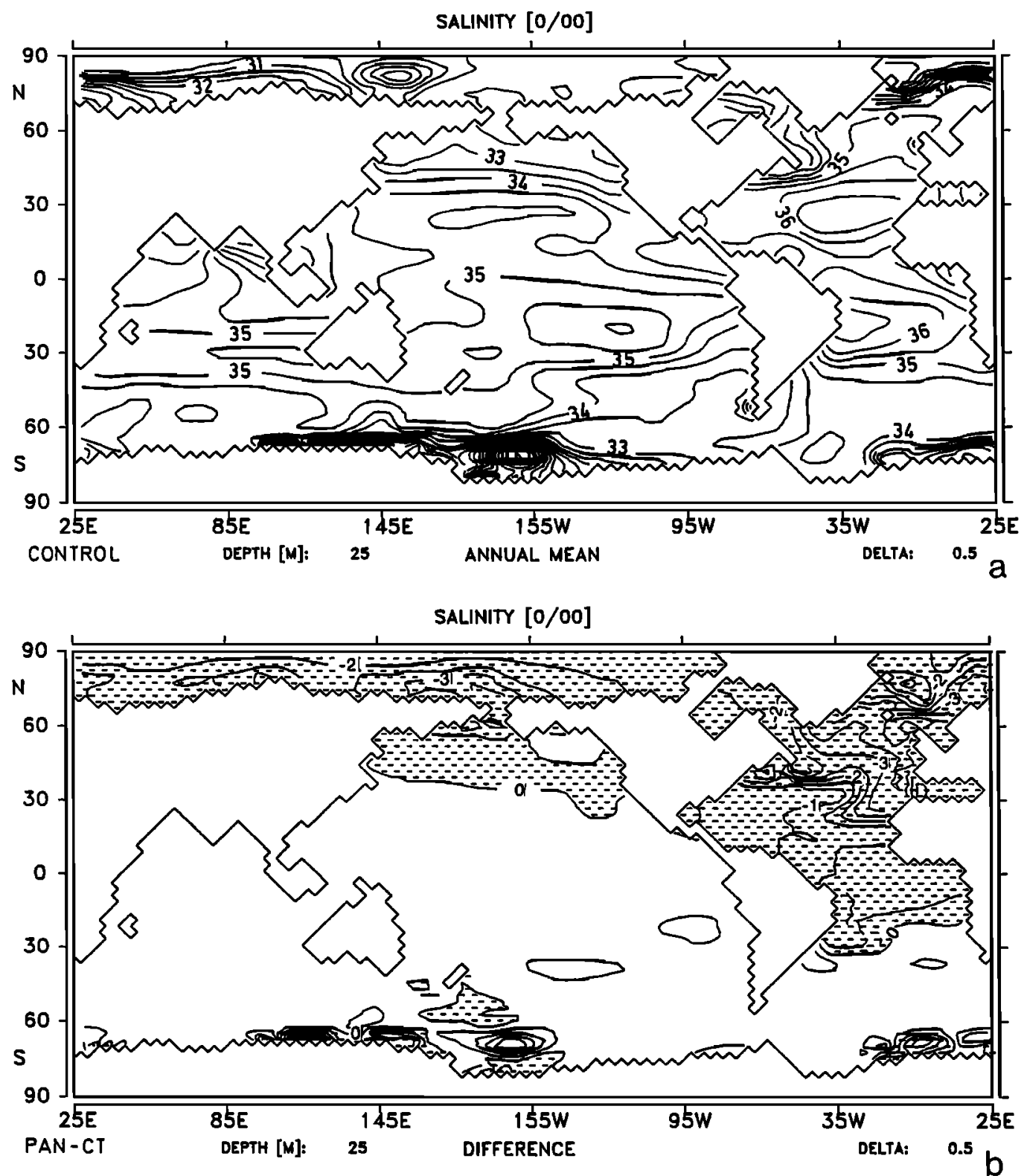

Fig. 5. Surface salinity (\%o) for (a) control and (b) Panama-minus-control differences. Horizontal dashes in shaded areas indicate lower salinity in perturbed run.

Atlantic exports about $17 \mathrm{~Sv}$ of deep water across the equator and, in order to conserve volume, it imports about $17 \mathrm{~Sv}$ of warm South Atlantic water. With NADW production reduced to essentially zero, there is no need to import South Atlantic surface water. The South Atlantic gyre correspondingly warms, and southward poleward heat transport increases in the South Atlantic.

The net effect of the Atlantic thermohaline changes is a significant modification of the North and South Atlantic surface circulation, especially along the western boundary currents, where transport of the Gulf Stream decreases and transport of the Brazil Current increases (Plate 1c). In both the control run (Plate 1a) and in nature, the velocities of these two currents are quite different, despite the fact that the wind-driven contribution to the currents is approximately the same. Stommel [1965, pp. 169-170] conjectured that the reason for the present difference involves interactions between the surface and deepwater circulations. The latter is counter to surface flow in the North Atlantic and in the same direction 

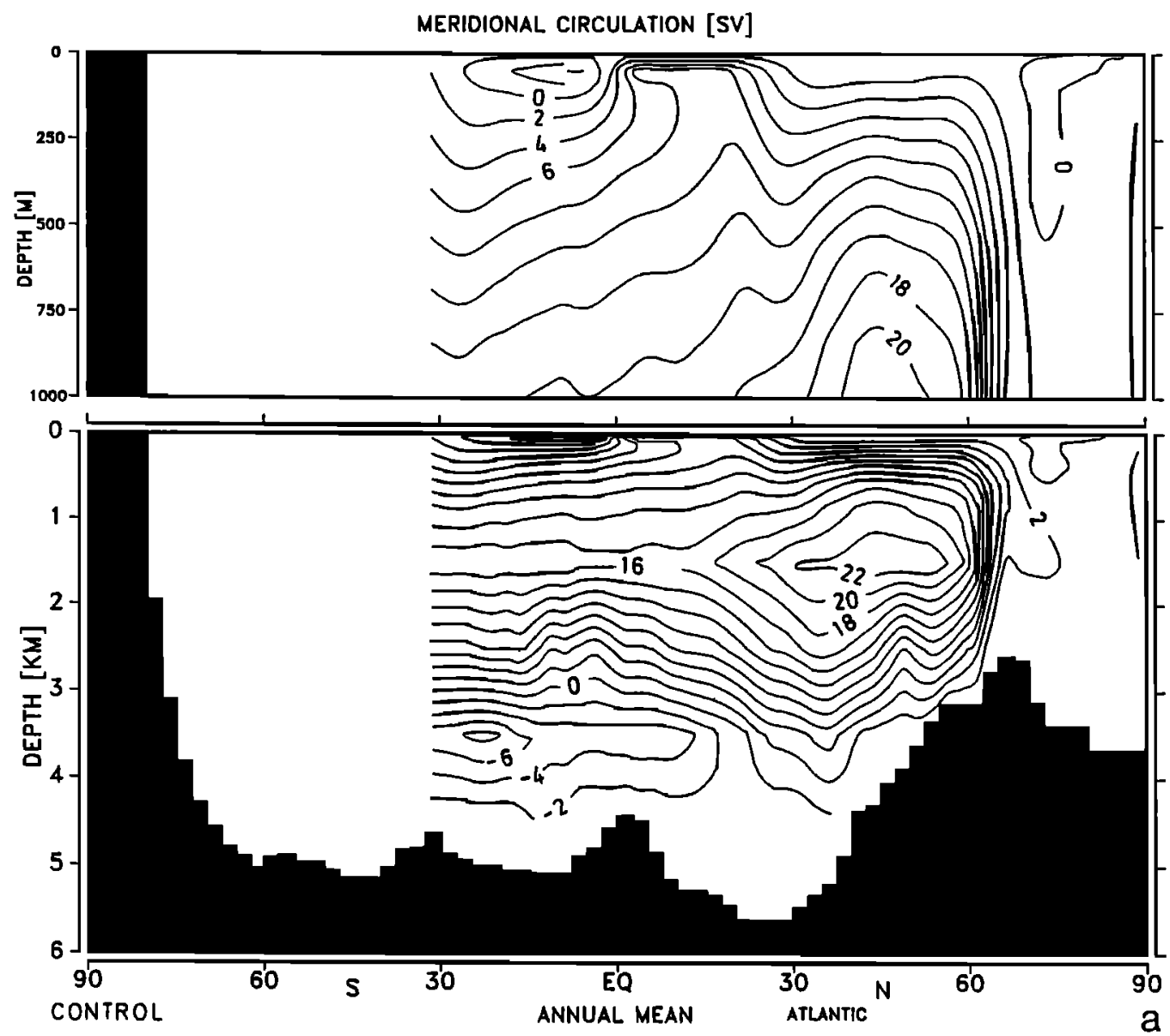

Fig. 6. Meridional circulation (Sv), Atlantic basin, (a) control and (b) Panama run. Positive sign indicates clockwise meridional flow pattern viewed from reader's perspective.

in the South Atlantic. This configuration results in a reinforcement of western boundary current flow in the North Atlantic, with the South Atlantic situation quite the contrary. Our calculation, which essentially eliminates the Atlantic deep-water cell, "restores" the near-symmetry in surface circulation in the two subtropical gyres (Plate 1 b), thereby supporting Stommel's 25-year old conjecture.

Additional changes occur in the southern ocean. Dilution of the North Atlantic surface waters increases slightly $(0.2 \%$ ) surface salinities in most other regions (Figure 5b). The slightly higher surface salinities in Antarctic regions cause about a 25\% greater Antarctic Bottom Water (AABW) outflow in the perturbed run (Figure 8). Enhanced AABW outflow then fills the central Pacific Basin with slightly younger water. This result is manifested in the model-simulated ${ }^{14} \mathrm{C}$ levels for the two experiments (Figure 9; the ${ }^{14} \mathrm{C}$ distribution can be simulated fairly realistically with a simple advective tracer model).

The net effect of many of the above changes can be summarized in the graphs for total ocean heat trans- port (Figure 10). The collapse of the thermohaline circulation in the North Atlantic greatly reduces the role of the ocean in transporting heat in this sector. Peak poleward ocean heat transport in the northern hemisphere is about one-third the present level. Peak southern hemisphere poleward ocean heat transport increases by about $25 \%$ in the perturbed run.

\section{DISCUSSION}

Testing for uniqueness. The results presented above indicate a collapse of the North Atlantic thermohaline circulation with an open central American isthmus. Before the geologic significance of this result can be evaluated, it is first necessary to consider whether the open isthmus is the primary cause of the altered circulation. This inquiry is necessary because modeling studies have shown that more than one mode of NADW formation may apply with the present geography and identical levels of forcing [Manabe and Stouffer, 1988; cf. Broecker et al., 1985; Bryan, 1986; Marotzke et al., 1988]. Similar 

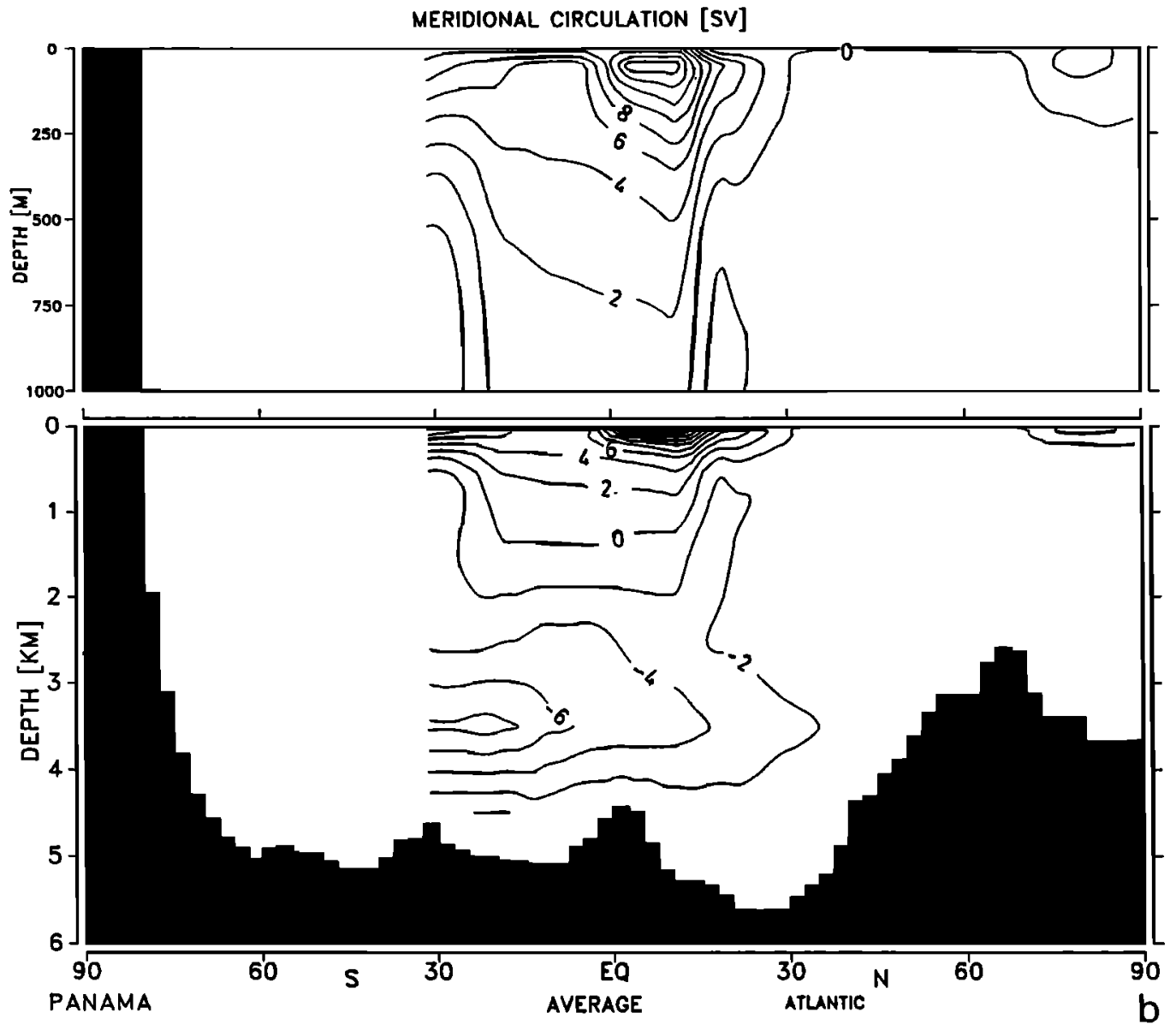

Fig. 6. (conlinued)

results have been obtained with the Hamburg model (E. Maier-Reimer, unpublished results, 1989).

Before proceeding to the discussion of the experiments for testing uniqueness, we note that it is unlikely that initial surface salinities in the key area of NADW formation would have been the same with an open isthmus. Removing the barrier should have mixed water masses of the North Atlantic and North Pacific, which would have resulted in an average surface salinity decrease in the North Atlantic of $\sim 1.0 \%$ (based on the ratio of areal differences in the basins of $\sim 1: 1.6$ and salinity differences of $\sim 1.5 \%$; North Pacific basin area was estimated only for 0$45^{\circ} \mathrm{N}$, as regions northward were not involved in direct exchange through the open isthmus). Observations indicate that interdecadal changes in North Atlantic thermohaline flow are associated with salinity changes of as little as $0.02 \%$ [ [Brewer et al., 1983; Levitus, 1989]. Other calculations with the Hamburg model suggest sensitivity of NADW production rates to salinity variations considerably less than 0.5\% [Maier-Reimer and Mikolajewicz, 1989].

Although it is impossible to prove uniqueness, we conducted two additional experiments in order to in- crease the likelihood of uniqueness. In the first experiment we opened the isthmus and continued the prescription of modern sea surface salinity for $\mathbf{5 0 0}$ years. After this integration time the total NADW production remained almost unchanged from the present day mode. At the open isthmus the southward flow of deep Atlantic water was partly deflected into the Pacific (not shown), compensated by a strong eastward surface flow of low-salinity water. After the switch to the prescription of freshwater fluxes, the circulation moved within a few centuries to the previously discussed mode.

In a second experiment we started with a homogeneous ocean and an open isthmus. Again, results converged rapidly on the "no-NADW" mode. As a demonstration of how the different experiments all converge on the same solution, Figure 11 illustrates the time series of the heat flux integrated over the Arctic and the Atlantic north of $30^{\circ} \mathrm{N}$. We chose this quantity because it is a convenient diagnostic for Atlantic modality (heat flux varies as the rate of northward moving water of low-latitude origin, with the rate of northward motion dependent on the rate of deep-water production). 


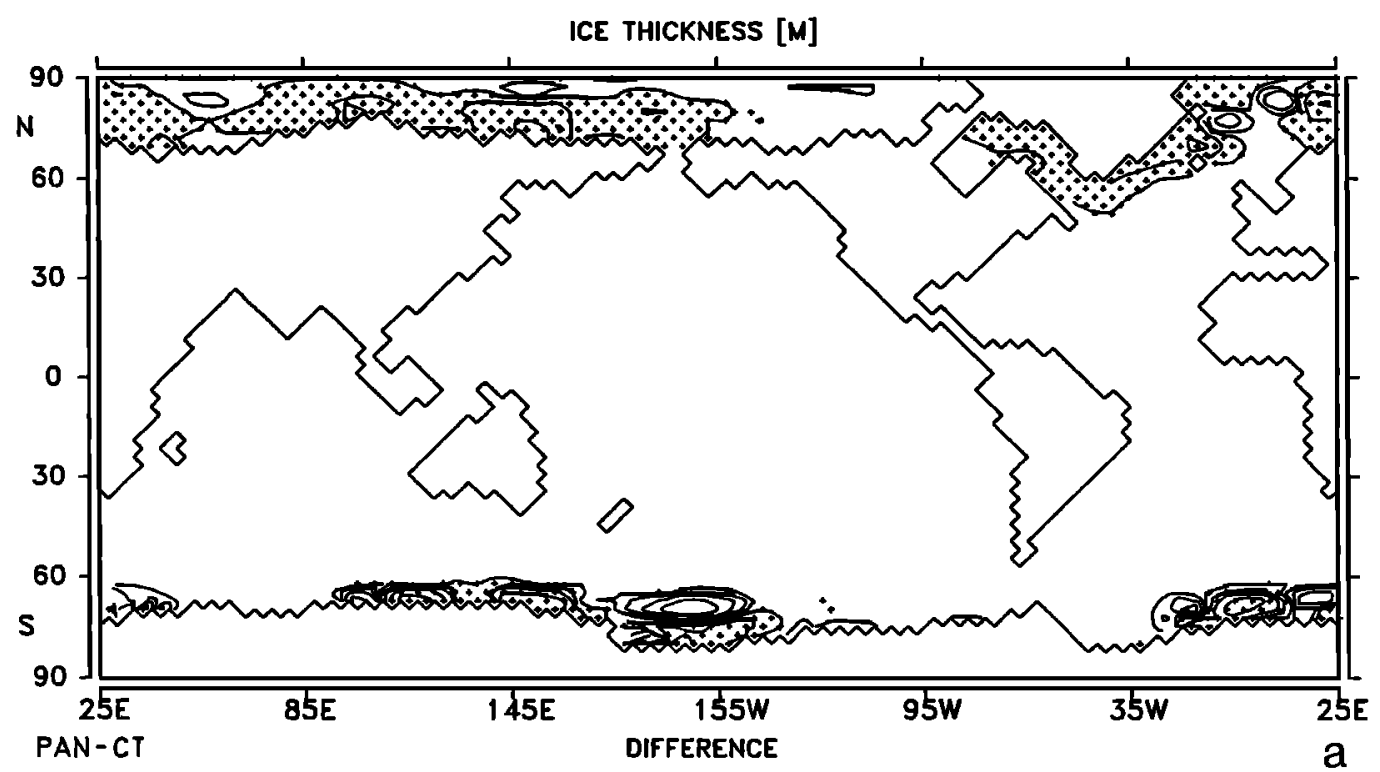

HEAT FLUX (DIAGNOSTIC) [W/M**2]

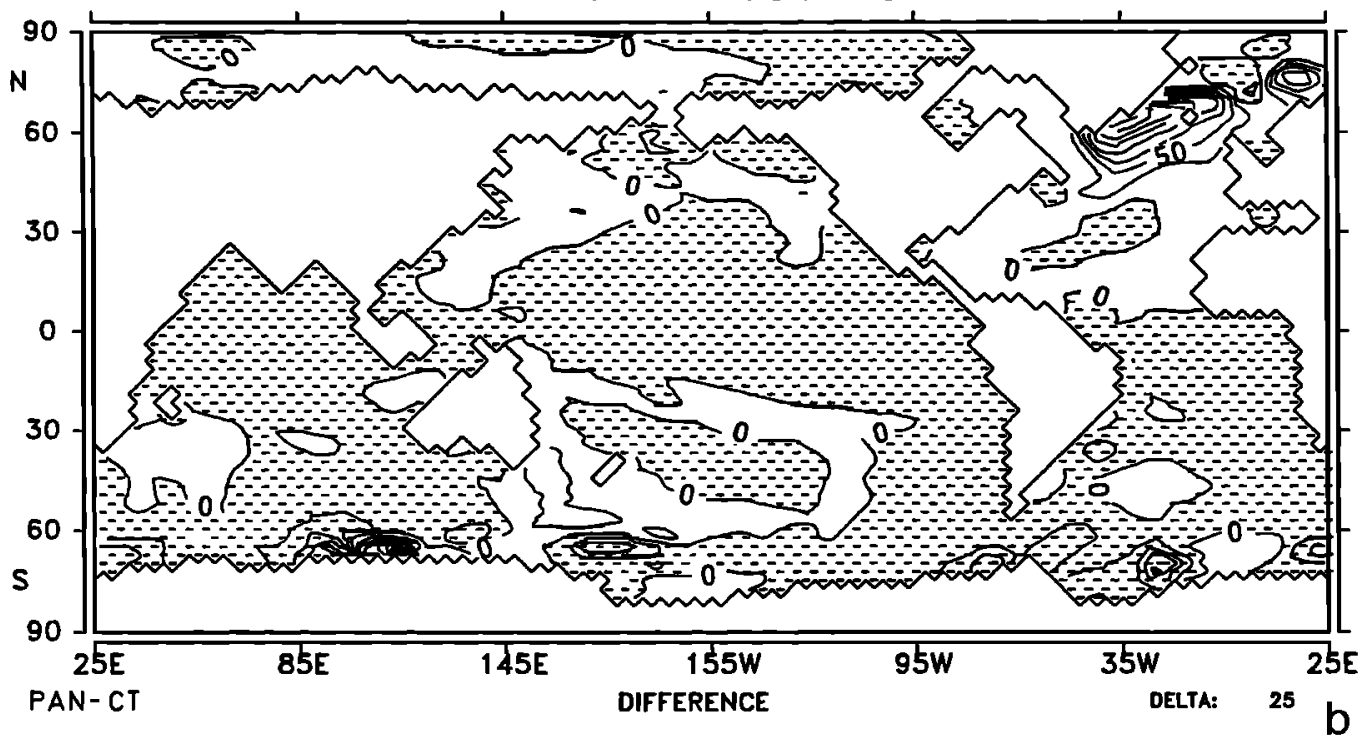

Fig. 7. Panama-minus-control differences in (a) sea ice thickness (meters); shaded areas with crosses indicate regions of increased sea ice thickness in perturbed run; and (b) heat flux $\left(\mathrm{W} / \mathrm{m}^{2}\right)$. Positive values in Fig. $7 \mathrm{~b}$ indicate areas where the ocean is losing less heat to the atmosphere in the perturbed run.

Figure 11 illustrates that the model converges on the same solution with three different initial conditions. This "no-NADW" mode is significantly different than a "low-NADW" mode obtained when we tested the Hamburg model for multiple stable states with present geography (E. Maier-Reimer, unpublished results, 1989). In the no-NADW mode there is $<1 \mathrm{~Sv}$ of cross-equatorial transport in the Atlantic, while in the low-NADW mode there is $\sim 6 \mathrm{~Sv}$ of cross-equatorial transport. These results, together with our discussion on the probability of significantly different initial conditions with an open isthmus, suggest that the circulation pattern with an open isthmus is different from any pattern resulting from perturbation of the model with present boundary conditions.

Sensitivity of results to prescribed boundary conditions. The results discussed above represent a sensitivity experiment. How might these results have been affected by past changes in atmospheric 

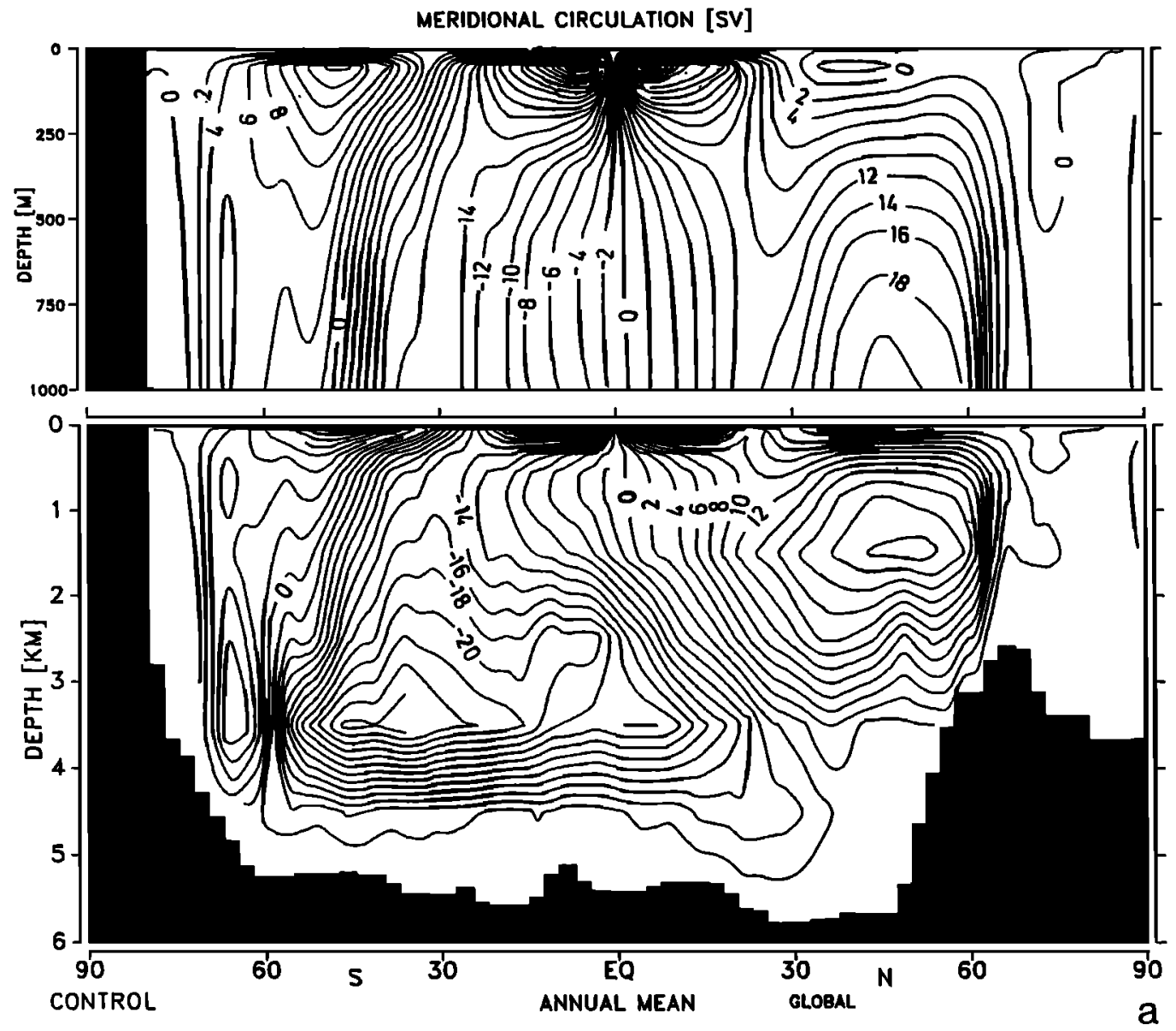

Fig. 8. Meridional circulation, global ocean, for (a) control run and (b) Panama run. Negative sign indicates counterclockwise meridional flow pattern viewed from reader's perspective. Note the greater outflow of AABW in the perturbed run.

forcing or by size of the central American opening? Complete assessment of these uncertainties requires more numerical experimentation. However, some points can be addressed in a preliminary way.

Prior to $3 \cdot 0-4.0 \mathrm{Ma}$ it is generally thought that there was less northern hemisphere ice cover than at present. The most likely changes in atmospheric forcing prior to $3.0 \mathrm{Ma}$ might therefore have involved changes due to decreased Arctic ice cover and perhaps a reduced Greenland Ice Sheet. These changes could affect the ocean circulation in at least two ways. Altered ice area and salinities in the polar North Atlantic could affect thermohaline overturn. Altered ice cover could also affect the atmospheric circulation, which could conceivably affect atmospheric forcing in the equatorial regions. However, sensitivity experiment with an atmospheric GCM indicate that reduced Arctic ice cover resulted in only minor changes in atmospheric forcing in regions $>1500 \mathrm{~km}$ away from the Arctic [Raymo et al., this issue]. This result is consistent with a sensitivity experiment at 18,000 years B.P. [Manabe and Broccoli, 1985], in which there was a relatively minor "far-field" (i.e., equatorial) effect due to highlatitude changes; the thermal perturbation in high latitudes is radiated away before it can significantly influence low-latitude processes [cf. North, 1984].

The stipulated size of the central American opening is also another uncertainty. However, we would expect that the sill depth would have to be raised considerably from its prescribed level of $2711 \mathrm{~m}$ before exchange would be significantly altered. We base this conjecture on the fact that exchange in surface waters between the North Atlantic and North Pacific is triggered by east-west differences in surface topography. Changes in topography are due primarily to changes in water column density above the thermocline. Thus we would not expect any large differences in model results unless we had a fairly shallow sill. However, horizontal constriction of the 


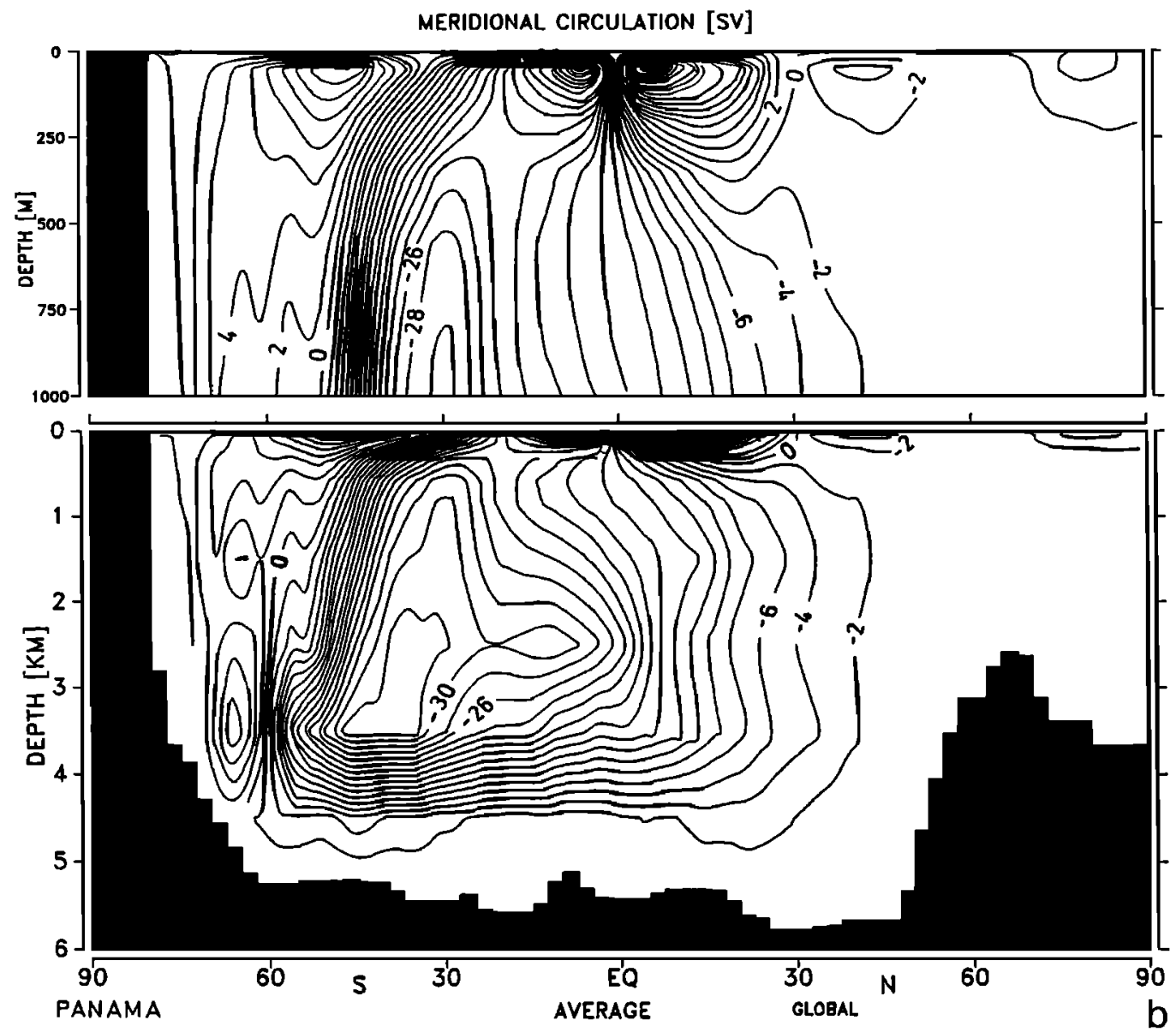

Fig. 8. (continued)

opening (cf. Figure 1) may well affect interocean exchange. We hope to test this latter effect in future experiments.

It is also necessary to recall that there are multiple sites of NADW formation at present. The water mass overflowing the Greenland-Scotland ridge is a result of complex vertical and horizontal mixing processes that occur in various basins and shelf areas to the north [e.g., Worthington, 1976; Aagaard et al., 1985]. If the model does not simulate all of these processes accurately, then there is some uncertainty in results for perturbed cases. This subject requires further research. However, we note that the salinity changes in surface waters for the perturbed case are so large that they may overwhelm some of the subtle processes discussed above.

Comparison with geologic observations. How do the model results compare with geologic data? The model makes several predictions: (1) the surface salinity and thermohaline circulation in the North Atlantic are significantly different from the present; (2) there is relatively little effect of the altered flow on eastern equatorial Pacific upwelling; and (3) AABW production is enhanced.

Although we cannot evaluate all of the above points with complete satisfaction, we note the agreement with some geologic data. For example, analysis of upwelling records in the eastern equatorial Pacific indicates that closure of the central American isthmus had relatively little effect on the upwelling [Hays et al., 1989]. Similarly, the strength of the western boundary current through the Yucatan Channel and Florida Straits was apparently weaker prior to about 3.0 Ma [Kaneps, 1979; Brunner, 1983/1984].

There is also some agreement between the model and observations with respect to salinity differences in the two basins. A comparison of mixed-layer $\delta^{18} \mathrm{O}$ records from the eastern equatorial Pacific and Caribbean indicates that prior to $4.0 \mathrm{Ma}$ the isotopic values in the two areas were the same (Figure 12) [Keigwin, 1982a], with Pliocene Caribbean values the same as present (low salinity) Pacific values. The $0.6-1.0 \% \circ \delta^{18} \mathrm{O}$ depletion in Caribbean Pliocene 

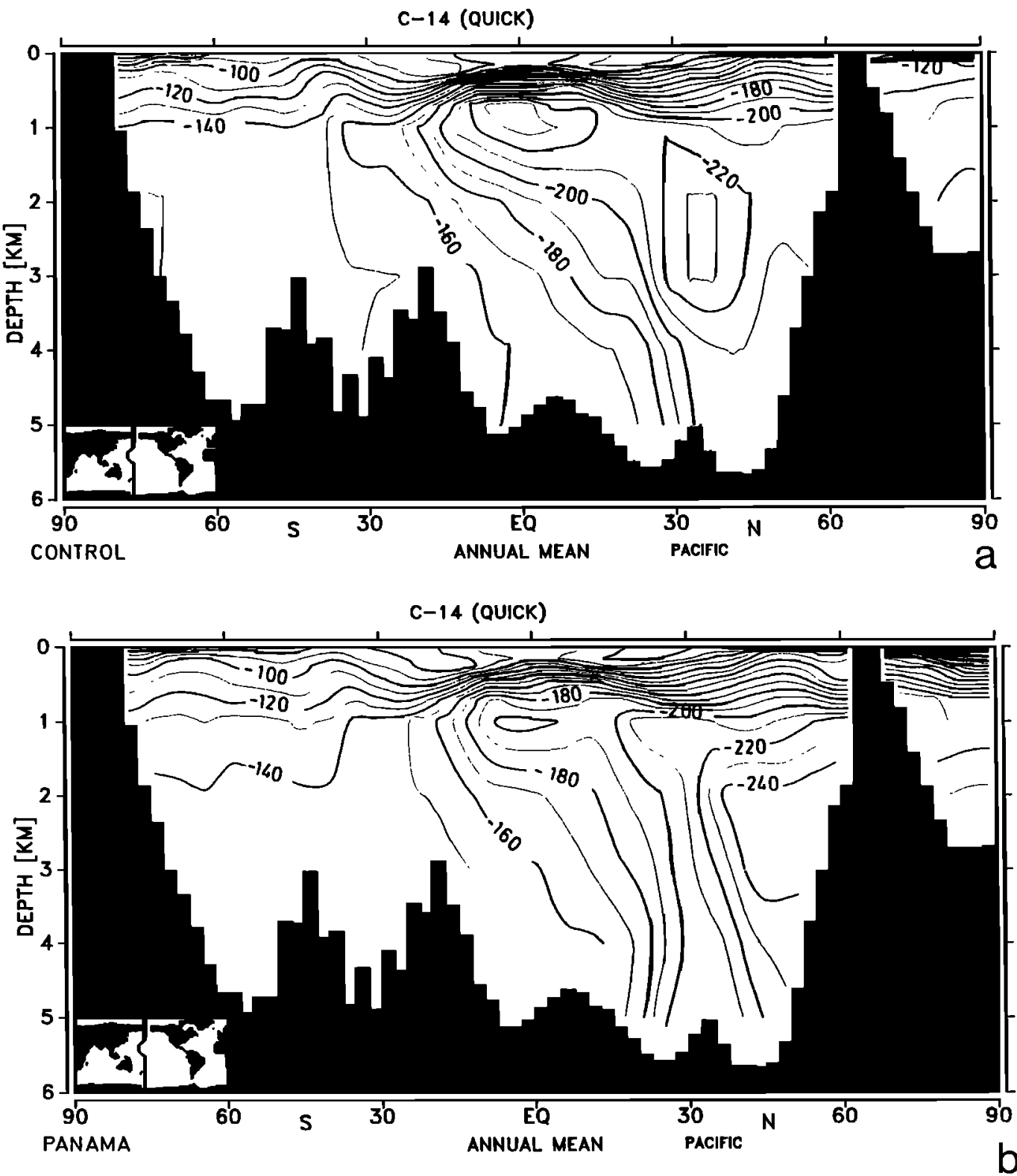

Fig. 9. Model-generated ${ }^{14} \mathrm{C}$ values for (a) control and (b) Panama run. Note lower (=younger) values in the central Pacific for Panama run.

records is also consistent with the effect of mixing water masses in the two basins (see section on uniqueness; Broecker [1989] has shown that an $\sim 1.0 \%$ o salinity difference is associated with $\sim 0.5 \%$ 。 $\delta^{18} \mathrm{O}$ difference).

The model also predicts that NADW production was significantly reduced prior to 3.0-4.0 Ma. Again, there is some agreement with geologic conclusions based on differences in $\delta^{13} \mathrm{C}$ of bottom waters between the two basins $\left(\Delta \delta^{13} \mathrm{C}_{\mathrm{A}-\mathrm{P}}\right)$. At present this difference is close to $1.0 \%$ and is due to pro- duction of isotopically heavy NADW. Prior to 3.04.0 Ma this difference was less [Miller and Fairbanks, 1985; Curry and Miller, 1989; Woodruff and Savin, 1989]. Our no-NADW result is also consistent with cadmium/calcium measurements for the Mid-Miocene ( $15 \mathrm{Ma})$, which show no significant differences between the Atlantic and Pacific [M. Delaney, personal communication, 1990].

The geologic record indicates that the temporal evolution of NADW production is more complicated than the presence-absence case we have addressed. 

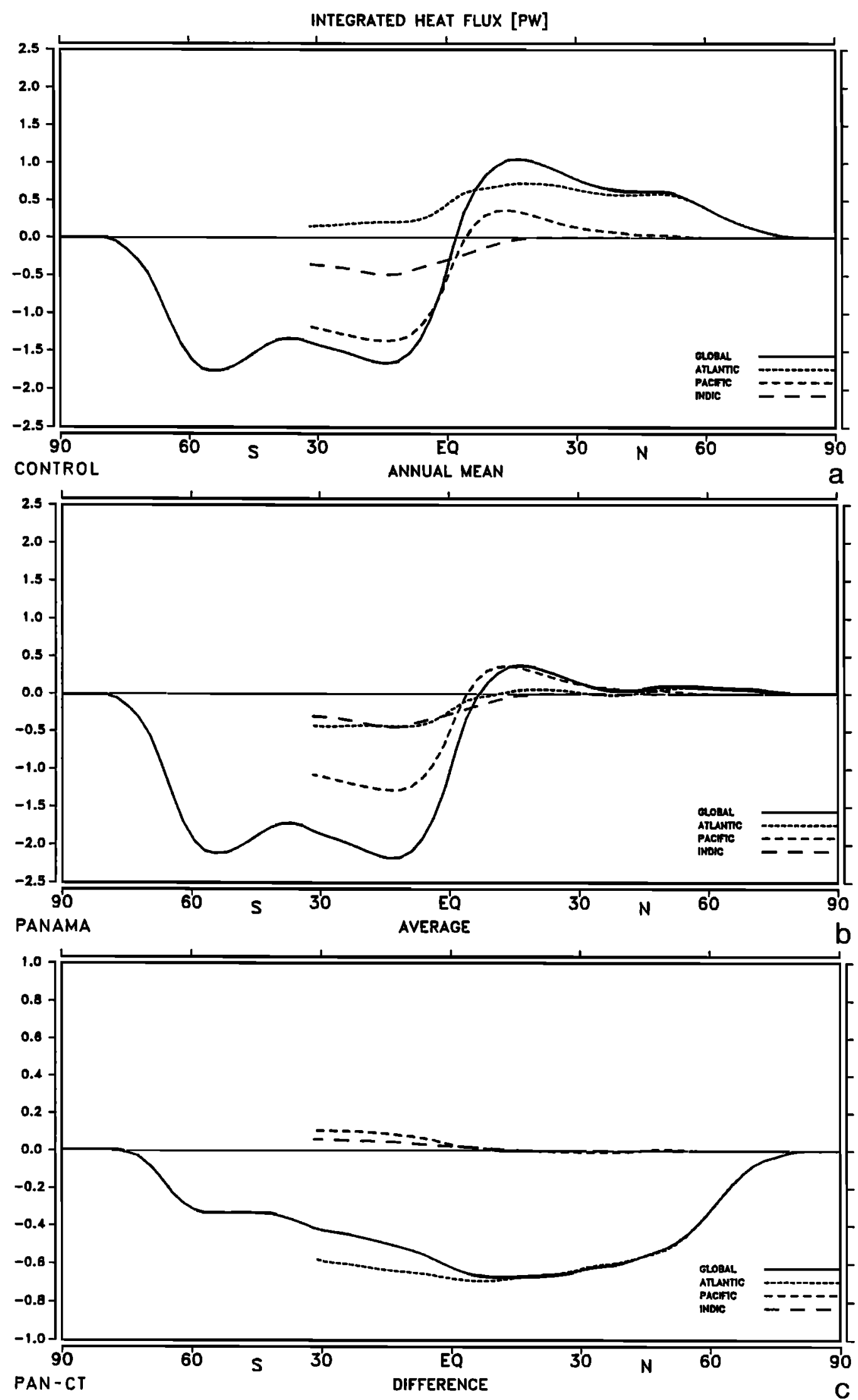

Fig. 10. Poleward ocean heat transport for (a) control, (b) Panama, and (c) Panama-minus- control. 


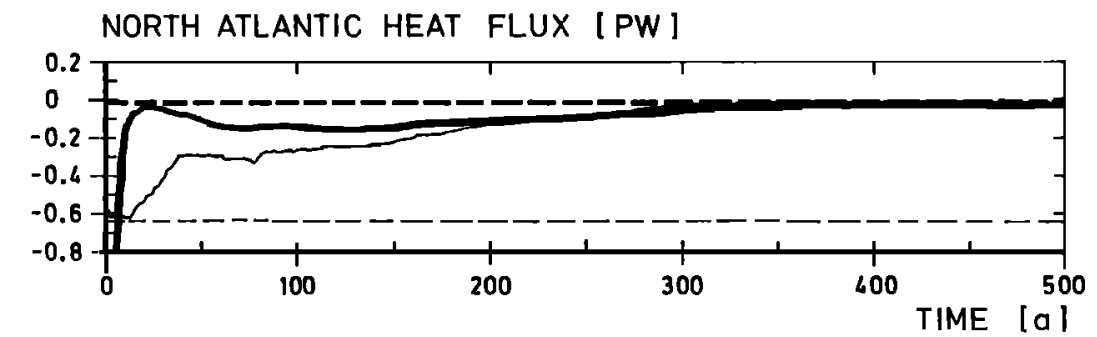

Fig. 11. Model sensitivity to initial boundary conditions. Figure illustrates heat loss from ocean to the atmosphere north of $30^{\circ} \mathrm{N}$ in the Atlantic and Arctic (negative values imply heat loss of ocean) versus integration time in model years. Thin dashed line equals average of control run (years 3500-4000); thick dashed line shows the same for last 500 years of Panama run (years 8000-8500); thin line equals the evolution after spin up with open isthmus and prescribed salinity; thick line equals spinup from homogeneous ocean with open isthmus.

Records of $\Delta \delta^{13} C_{A-P}$ and of sediment redistribution in the North Atlantic indicate that NADW was being at least intermittently formed as early as $30 \mathrm{Ma}$ [Miller and Tucholke, 1983; Miller and Fairbanks, 1985]. Furthermore, Woodruff and Savin [1989] conclude that NADW production was more common after 10-12 Ma, significantly before final closure of the isthmus. This conclusion is in agreement with records of silica accumulation in the two basins (Figure 13). At present silica tends to accumulate in older deep waters, such as the North Pacific. Prior to 10-11 Ma silica accumulation in the Atlantic was much more common [Keller and Barron, 1983]. This pattern is also consistent with carbonate accumulation rate changes in the equatorial Pacific [van Andel et al., 1975]. The latter can vary inversely with silica [cf. Berger, 1970], and carbonate accumulation decreased in the equatorial Pacific at the same time that Pacific silica deposition was increasing.

We conjecture that the "early" transition in NADW production and sediment accumulation may reflect near-closure of the isthmus by 7-10 Ma (cf. Figure 1 ); i.e., that constriction tilted the circulation into a more active NADW mode. However, there would still be a greater tendency for weaker thermohaline overturn in the North Atlantic as long as the isthmus was open. This prediction is supported by relatively low $\Delta \delta^{13} C_{A-P}$ differences from 3.0 to $4.0 \mathrm{Ma}$ [Curry and Miller, 1989] and by records of biogenic accumulation in the Norwegian Sea [Henrich et al., 1989]. The latter indicates that as late as $2.4 \mathrm{Ma}$ (late Pliocene) in the Norwegian Sea, NADW production was relatively weak, carbonate accumulation was low, and silica accumulation was high.

Finally, we can make some preliminary statement about the consistency of model results with respect to changes in AABW formation. The model predicts that the younger central Pacific deep waters should be less undersaturated than present with respect to carbonate ion concentration. All other factors being held constant, these changes should be manifested as better preservation of Pacific carbonate prior to about
3.0 Ma. In fact, there is some indication that Pacific records older than 3.0-4.0 Ma are a more "Atlantic type" (i.e., high carbonate) pattern [Dunn et al., 1981; Dunn, 1982; cf. van Andel et al., 1975]. It

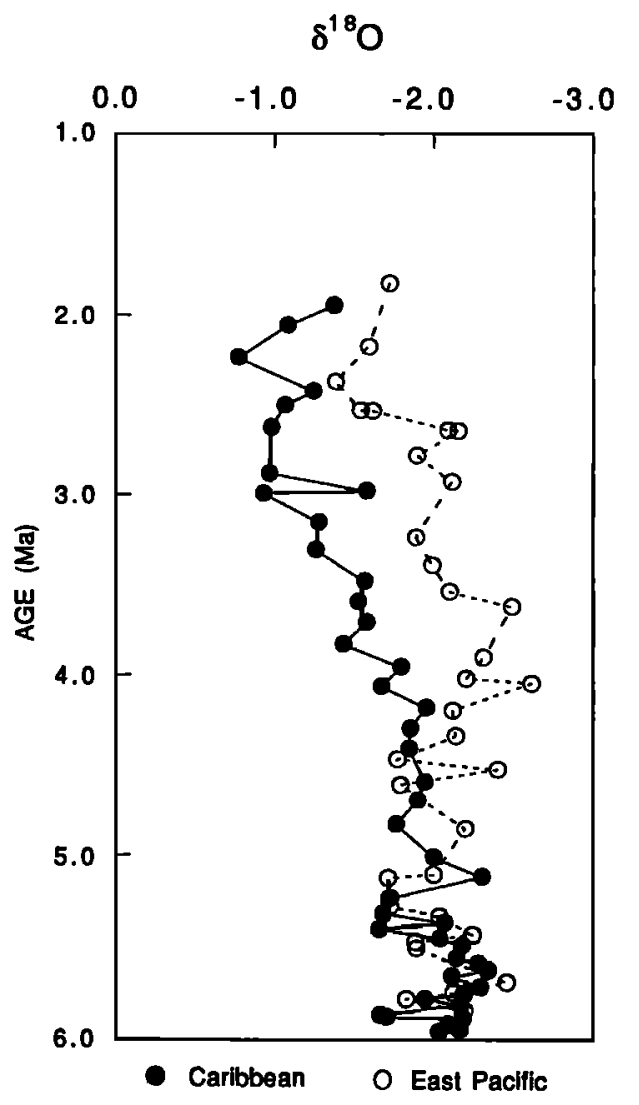

Fig. 12. The $\delta^{18} \mathrm{O}$ values of mixed-layer planktonic foraminifera Globigerinoides sacculifer for the interval approximately 2.0-6.0 Ma in cores from the Caribbean and eastern equatorial Pacific [after Keigwin, 1982a]. Note the similar values prior to about $4.0 \mathrm{Ma}$, which correspond approximately to a 1.0 $1.5 \%$ salinity decrease in the Caribbean. 


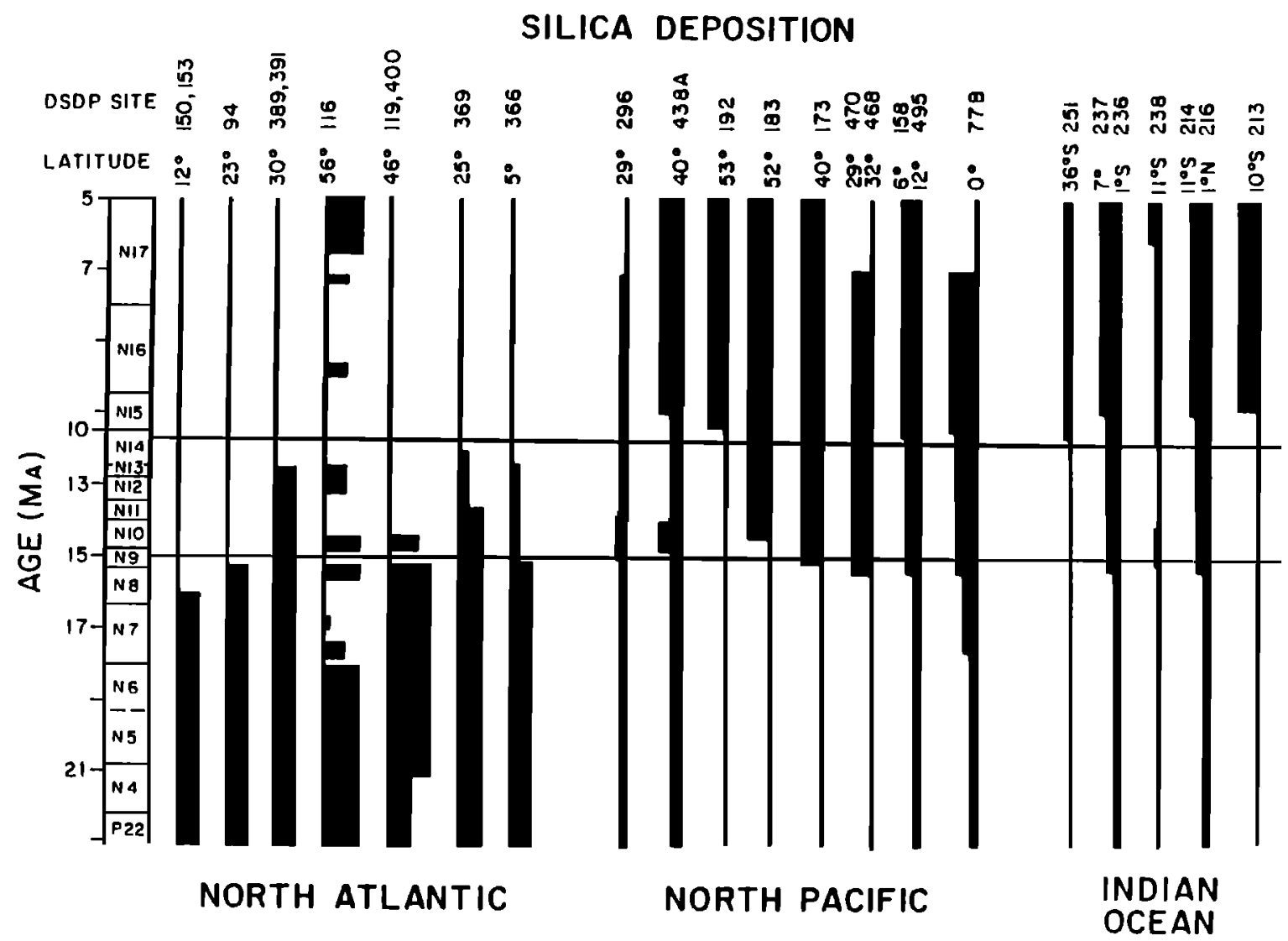

Fig. 13. Compilation of regional patterns of silica deposition in the world ocean from 5 to 23 Ma (from Woodruff and Savin [1989], who based their work on data from Keller and Barron [1983]). Note that prior to about 10-12 Ma, silica deposition was more common in the North Atlantic and that after time it was more common in the North Pacific. However, silica deposition persisted in the North Atlantic as late as $2.4 \mathrm{Ma}$ (see text).

would be desirable to test this agreement with more data. Note however that deep-water production patterns may not be the only factor governing temporal changes in carbonate preservation, so there is a need for caution in interpreting the significance of either favorable or unfavorable agreement between models and observations with respect to this prediction.

\section{SUMMARY AND CONCLUSIONS}

1. We have tested the sensitivity of an ocean GCM to altered boundary conditions by opening the central American isthmus to mimic conditions existing prior to about 3.0-4.0 Ma.

2. The open isthmus radically affects the threedimensional circulation in the ocean. Most of the changes can be traced back to changes in west-east transport through the isthmus. At present, sea surface topography is about $80 \mathrm{~cm}$ higher in the western equatorial Pacific than in the western equatorial
Atlantic. With an open isthmus, adjustments to the hydrostatic head cause a moderately large west-toeast flow of relatively low salinity water from the Pacific to the North Atlantic basins. Lower surface salinity in the subpolar North Atlantic prevented NADW formation, which in turn reduced poleward heat transport in the North Atlantic.

3. Results have been tested for uniqueness. Although it is impossible to prove uniqueness, we demonstrate that the same "no-NADW" solution results from three different types of initial conditions. The no-NADW mode in our simulation is significantly different than a "low-NADW" mode produced by the Hamburg model for present geography.

4. There is some agreement between model results and geologic data, but there is a timing mismatch between final closure of the isthmus (3.0-4.0 Ma) and onset of a more vigorous thermohaline cell in the North Atlantic (10-12 Ma). However, geologic data still indicate a tendency for weak NADW production as late as 3.0-4.0 Ma. We conjecture that constric- 
tion of the opening as early as 7-10 Ma may have been responsible for this early shift, but that the tendency for weak thermohaline overtum persisted until the connection was sealed off. This conjecture requires further numerical testing.

5 . The model results suggest that an open central American isthmus exerts a significant influence on the long-term trends in deep-water circulation and basin-basin fractionation of biogenous sediments [cf. Berger, 1970].

6. Both the model and observations predict that the preglacial circulation in the Norwegian Sea was not just a warm version of a Pleistocene interglacial ocean; the circulation patterns for the two time periods may have been fundamentally different. Furthermore, since the North Atlantic circulation represents an important source of heat for the high latitudes of the North Atlantic, our results suggest that some compensating factor $\left(\mathrm{CO}_{2}\right.$ ?) was required to restore heat to this region during warmer intervals of the pre-Pleistocene [cf. Zubakov and Borzenkova, 1988].

Acknowledgments. We thank Klaus Hasselmann for his encouragement and support of this project. We have benefitted from comments by E. Barron, W. Broecker, K. Bryan, W. Curry, M. Delaney, J. Farrell, W. Hyde, L. Keigwin, J. Miller, and M. Sarnthein. We also thank $\mathbf{M}$. Böttinger and $\mathbf{M}$. Grunert for their help in production of figures. Funding for T.J.C. was partially provided by NSF grant ATM87-22145.

\section{REFERENCES}

Aagaard, K, J. H. Swift, E. C. Carmack, Thermohaline circulation in the Arctic Mediterranean seas, J. Geophys. Res., 90, 4833-4846, 1985.

Berger, W. H., Biogenous deep-sea sediments: Fractionation by deep-sea circulation, Deep Sea Res., 81, 31-43, 1970.

Berggren, W. A., and C. D. Hollister, Paleogeography, paleobiogeography, and the history of circulation in the Atlantic Ocean, Studies in PaleoOceanography, edited by W.W. Hay, Spec. Publ., Soc. Econ. Paleontol. Mineral., 20, 126186, 1974.

Brewer, P. G., et al., A climatic freshening of the deep Atlantic north of $50^{\circ} \mathrm{N}$ over the past 20 years, Science, 222, 1237-1239, 1983.

Broecker, W. S., The salinity contrast between the Atlantic and Pacific Oceans during glacial time, Paleoceanography, 4, 207-212, 1989.

Broecker, W. S., D. M. Peteet, and D. Rind, Does the ocean-atmosphere system have more than one stable mode of operation?, Nature, 315, 21-26, 1985.

Brunner, C. A., Evidence for increased volume transport of the Florida current in the Pliocene and Pleistocene, Mar. Geol., 54, 223-235, 1983/84.
Bryan, F., High-latitude salinity effects and interhemispheric thermohaline circulations, Nature, 323, 301-304, 1986.

Curry, W. B., and K. G. Miller, Oxygen and carbon isotopic variation in Pliocene benthic foraminifera of the equatorial Atlantic, in Proceedings of ODP Initial Report, vol. 108, pp. 157-166, Ocean Drilling Program, College Station, Tex., 1989.

Dunn, D. A., Changes from "Atlantic-type" to Pacific-type" carbonate stratigraphy in the middle Pliocene equatorial Pacific Ocean, Mar. Geol., $50,41-60,1982$.

Dunn, D. A., T. C. Moore, and L. D. Keigwin, Atlantic-type carbonate stratigraphy in the late Miocene Pacific, Nature, 291, 225-227, 1981.

Gordon, A. L., Interocean exchange of thermocline water, J. Geophys. Res., 91, 5037-5046, 1986.

Haq, B. U., Paleogene paleoceanography: Early Cenozoic oceans revisited, Proceedings $26^{\text {th }}$ International Geological Congress, Geology of Oceans symposium, Paris, July 7-17, 1980, Oceanol. Acta, 71-82, 1981.

Hasselmann, K., An ocean model for climate variability studies, Prog. Oceanogr., 11, 69-92, 1982.

Hastenrath, S., Heat budget of tropical ocean and atmosphere, J. Phys. Oceanogr., 10, 159-170, 1980.

Hays, P. E., N. G. Pisias, and A. K. Roelofs, Paleoceanography of the eastern equatorial Pacific during the Pliocene: A high-resolution radiolarian study, Paleoceanography, 4, 57-74, 1989.

Hellermann, S., and M. Rosenstein, Normal monthly wind stress data over the world ocean with error estimates, J. Phys. Oceanogr., 13, 1093-1104, 1983.

Henrich, R., T. C. W. Wolf, G. Bohrmann, and J. Thiede, Cenozoic paleoclimatic and paleoceanographic changes in the Northern Hemisphere revealed by variability of coarse fraction composition in sediments from Vøring Plateau-ODP leg 104 drill sites, in Proceedings of ODP, Initial Report, vol., 104, 75-188, Ocean Drilling Program, College Station, Tex., 1989.

Kaneps, A. G., Gulf stream: Velocity fluctuations during the late Cenozoic, Science, 204, 297-301, 1979.

Keigwin, L. D., Isotopic paleoceanography of the Caribbean and east Pacific: Role of Panama uplift in late Neogene time, Science, 217, 350-353, 1982a.

Keigwin, L. D., Neogene planktonic foraminifers from deep sea drilling project sites 502 and 503, Initial Rep. Deep Sea Drill. Proj., 68, 269-288, 1982b.

Keller, G., and J. A. Barron, Paleoceanographic implications of Miocene deep-sea hiatuses, Geol. Soc. Am. Bull., 94, 590-613, 1983.

Kennett, J. P., G. Keller, and M. S. Srinivasan, Miocene planktonic foraminiferal biogeography 
and paleoceanographic development of the IndoPâcific region, Mem. 163, Geol. Soc. Am., 197236, 1985.

Levitus, S., Climatological Atlas of the World Ocean, NOAA Prof. Pap. 13, U.S. Government Printing Office, Washington, D.C., 1982.

Levitus, S., Interpentadal variability of temperature and salinity in the deep North Atlantic, 1970-1974 versus 1955-1959, J. Geophys. Res., 94, 16,125-16,131, 1989.

Maier-Reimer, E., and K. Hasselmann, Transport and storage of $\mathrm{CO}_{2}$ in the ocean--An inorganic ocean-circulation carbon cycle model, Clim. Dynam., 2, 63-90, 1987.

Maier-Reimer, E., and U. Mikolajewicz, Experiments with an OGCM on the cause of the Younger Dryas, Tech. Rep. 39, Max-Planck-Inst. für Meteorol., Hamburg, West Germany, 1989.

Manabe, S., and A. J. Broccoli, The influence of continental ice sheets on the climate of an ice age, J. Geophys. Res., 90, 2167-2190, 1985.

Manabe, S., and R. J. Stouffer, Two stable equilibria of a coupled ocean-atmosphere model, $J$. Climatol., 1, 841-866, 1988.

Marotzke, J., P. Welander, and J. Willebrand, Instability and multiple steady states in a meridionalplane model of the thermohaline circulation, Tellus, 40A, 162-172, 1988.

Marshall, L. G., S. D. Webb, J. J. Sepkoski, and D. M. Raup, Mammalian evolution and the great American interchange, Science, 215, 1351-1357, 1982.

Miller, K. G., and R. G. Fairbanks, Oligocene to Miocene carbon isotope cycles and abyssal circulation changes, in The Carbon Cycle and Atmospheric $\mathrm{CO}_{2}$ : Natural Variations Archean to Present, Geophys. Monogr. Ser., vol. 32, edited by E. T. Sundquist and W. S. Broecker, pp. 469486, AGU, Washington, D.C., 1985.

Miller, K. G., and R. G. Tucholke, Development of Cenozoic abyssal circulation south of the Greenland-Scotland Ridge, in Structure and Development of the Greenland-Scotland Ridge, edited by M. H. P. Bott, S. Saxov, M. Talwani, and J. Thiede, pp. 549-589, Plenum, New York, 1983.

North, G. R., The small ice cap instability in diffusive climate models, J. Atmos. Sci., 41, 33903395, 1984.
Raymo, M. E., D. Rind, and W. Ruddiman, Climatic effects of variable Arctic sea ice in the GISS II General Circulation Model, Paleoceanography, this issue.

Slutz, R. J., S. J. Lubker, J. D. Hiscox, S. D. Woodruff, R. L. Jenne, D. H. Joseph, P. M. Steurer, and J. D. Elms, Comprehensive OceanAtmosphere Data Set: Release 1, 268 pp., Environmental Research Laboratories, Climate Research Program, Boulder, Colo., (Available as NTIS PB86-105723, from Natl. Tech. Inf. Serv., Springfield, Va.), 1985.

Stommel, H., The Gulf Stream (2nd Ed.), 248 pp., Univ. California Press, Berkeley, Calif., 1965.

Sykes, L. R., W. R. McCann, and A. L. Kafka, Motion of Caribbean plate during last 7 million years and implications for earlier Cenozoic movements, J. Geophys. Res., 87, 1065610676, 1982.

van Andel, T., G. R. Heath, and T. C. Moore, Jr., Cenozoic history of the central equatorial Pacific Ocean, Mem. Geol. Soc. Am., 143, 1-134, 1975.

Woodruff, S. D., R. J. Slutz, R. J. Jenne, and P. M. Steurer, A comprehensive ocean-atmosphere data set, Bull. Am. Meteorol. Soc., 68, 1239$1250,1987$.

Woodruff, F., and S. M. Savin, Miocene deep-water oceanography, Paleoceanography, 4, 87-140, 1989.

Worthington, L. V., On the North Atlantic Circulation, 110 pp., Johns Hopkins University Press, Baltimore, Md., 1976.

Zubakov, V. A., and I. I. Borzenkova, Pliocene palaeoclimates: Past climates as possible analogues of mid-twenty-first century climate, Palaeogeog., Palaeoclimatol., Palaeoecol., 65, 35-49, 1988.

T. J. Crowley, Applied Research Corporation, 305 Arguello Drive, College Station, TX 77840.

E. Maier-Reimer and U. Mikolajewicz, MaxPlanck-Institut für Meteorologie, Bundesstrasse 55, D-2000 Hamburg 13, Federal Republic of Germany.

(Received September 1, 1989; revised February 16, 1990; accepted February 16, 1990.) 